\title{
INFORMATION SYSTEMS AND TECHNOLOGIES
}

DOI https://doi.org/10.30525/978-9934-26-046-9-1

\section{МЕТОДИКИ ОБГРУНТУВАННЯ ВИБОРУ РОЗВІДУВАЛЬНО-ВОГНЕВИХ СИСТЕМ $З$ УРАХУВАННЯМ УМОВ ВЕДЕННЯ ВІЙСЬКОВИХ (БОЙОВИХ) ОПЕРАЦІЙ}

\author{
Адаменко М. В. \\ кандидат військових наук, \\ начальник науково-дослідної лабораторї кафедри розвідки \\ Національний університет оборони Украӥни \\ імені Івана Черняховського \\ м. Київ, Украӥна \\ Ліцман А. М. \\ кандидат технічних наук, \\ начальник науково-дослідного відділу \\ Науково-дослідний цеентр ракетних військ $і$ артилерї \\ м. Суми, Украӥна \\ Грохольський Я. М. \\ кандидат технічних наук, дочент, \\ доиент кафедри автоматизованих систем управління \\ Військовий інститут телекомунікацій та інформатизації \\ імені Героїв Крут \\ м. Київ, Украӥна
}

Вступ. Результати аналізу воєнних конфліктів останніх десятиліть переконливо свідчать про зростаючу роль розвідувально-вогневих систем (РВС). Так починаючи з операції «Буря в пустелі» 1991 року [1] до АТО (ООС) на Сході України $[2,3]$ частка виконання завдань щодо ураження цілей зросла із 10-30 \% до 50-90\%. Однак, із зростанням залучення РВС до виконання завдань було виявлено низку проблем, які впливають на ефективність їх застосування.

Так, однією з проблем є комплектування РВС елементами з різними можливостями. Включення до РВС засобів польової артилерії (ракетних військ і артилеріï), які можуть виконувати завдання із інте- 
нсивністю та імовірністю виконання значно більшою ніж можливості засобів розвідки [4]. Або залучення такої кількості засобів розвідки, які значно переважають по пропускній спроможності засоби управління та передачі даних [4].

Наступною суттєвою, на думку авторів, проблемою $є$ неврахування (не достатнє врахування) стійкості функціонування РВС [4]. Так доволі часто при плануванні військових (бойових) операцій враховується лише статична протидія противника, тобто така, яка залежить лише від можливостей самого противника без врахування дій $[1,3]$.

Означені проблеми при виникненні одночасно можуть повністю нівелювати позитивний ефект від застосування РВС i, загалом, призведуть до організаційних проблем. Такими проблемами можуть бути: складність вибору найбільш важливих властивостей РВС, неможливість визначити обгрунтовану перевагу певної РВС перед іншою. Тому, розроблення методики такого обгрунтування, зважаючи на зростаючу роль РВС у проведенні військових (бойових) операцій, $\epsilon$ актуальним.

Виклад основного матеріалу дослідження. Загалом методика вибору РВС базується на методові аналізу. Відповідно до суті методу проведено попарне порівняння визначених критеріїв за усіченим варіантом шкали Сааті. Надалі проведено визначення оцінки компоненти власного вектору за відомою формулою знаходження середнього геометричного значення.

Далі проводиться нормалізацію оцінки вектору пріоритету за розрахунковою залежністю

В подальшому, для перевірки правильності суджень експертів, проводиться визначення параметрів індексу узгодженості та відношення узгодженості за розрахунковими залежностями. Причому відношення узгодженості не повинно перевищувати межу $10 \%$, в іншому випадку необхідно переглянути судження експертів.

В подальшому проводиться попарне порівняння РВС відносно кожного з критеріїв.

Надалі проводиться визначення глобальних пріоритетів РВС відносно кожного $з$ критеріїв відбору шляхом внесення в таблицю значень нормалізованих оцінок векторів пріоритетів по РВС відносно кожного 3 критеріїв та нормалізованих оцінок векторів пріоритетів критеріїв. Розрахунок глобальних пріоритетів проводиться за відомою розрахунковою залежністю.

Результати аналізу отриманих даних свідчить, що апаратнопрограмний комплекс автоматизованого управління вогнем артиле- 
рійського підрозділу ArtOS має суттєву перевагу порівняно з іншими аналогічними засобами від 17 до $22 \%$.

Загалом результати проведеного дослідження можливо розділити на три частини. Першим результатом є обгрунтування критеріїв вибору РВС на підставі кластерного аналізу вимог до них обумовлених особливостями проведення військових (бойових) операцій. Другим результатом $\epsilon$ розроблення методики обгрунтування вибору РВС 3 урахуванням умов ведення військових (бойових) операцій.

Зрозуміло, що означений підхід до обгрунтування вибору РВС для умов військових (бойових) операцій не позбавлений недоліків.

По-перше, це суб'єктивізм. Адже за основу в цій методиці приймається досвід експертів. Хоча зважаючи на значну кількість військових конфліктів у світі, можна вважати, що досвід у військових фахівців $\epsilon$ достатнім для використання означеної методики.

До того ж, особливість метода щодо перевірки узгодженості оцінок підвищує адекватність означеної методики.

Стосовно переваг цього підходу можна зазначити відносну його простоту. Також беззаперечною перевагою цієї методики $є$ іiї модульність. Тобто здатність замінювати певні блоки іншими більш доцільними для умов певної операції.

\section{Висновки:}

1. Визначено, що особливостями проведення військових (бойових) операцій на сучасному етапі розвитку воєнного мистецтвам є: швидка зміна обстановки, змагання із противником за виграш у часі, точності, маневреності, скритності. Також до особливостей відносяться: великий обсяг даних якими необхідно оперувати під час прийняття рішення на бойове застосування (бойові діï). Ще особливостями сучасних військових (бойових) операцій $є$ : узгодженість дій та чітка структура підпорядкованості; автономність щодо забезпечення та місцеположення.

2. Визначено вимоги до РВС обумовлених специфікою проведення військових (бойових) операцій та на підставі їх аналізу сформульовано критеріїв відбору РВС, зокрема: оперативність, точність, скритність, стійкість.

3. Проаналізовано існуючі РBC тактичного рівня (C2-C2SR), які були створені за останні роки, та які мають відкриту інформацію про ïx характеристики. Зокрема, проаналізовані такі системи: бойова система управління тактичної ланки «Кропива» (Україна), апаратнопрограмний комплекс автоматизованого управління вогнем артилерійського підрозділу «ArtOS» (Україна), автоматизована система 
управління «Оболонь-А» (Україна), ударно-розвідувальний комплекс «Сокіл» (Україна, Польща).

4. Розроблено методику обгрунтування вибору РВС з урахуванням умов ведення військових (бойових) операцій, яка грунтується на методах аналізу ієрархій, кластерного аналізу та експертного оцінювання. Означена методика дозволяє узгодити особливості проведення військових (бойових) операцій, досвід експертів та вимоги до РВС.

5. Визначено, під час розрахунку прикладу вибору РВС, що апаратно-програмний комплекс автоматизованого управління вогнем артилерійського підрозділу ArtOS має перевагу порівняно з іншими аналогічними засобами від 17 до $22 \%$.

\section{Література:}

1. Lingamfelter, L. Desert Redleg: Artillery Warfare in the First Gulf War. 2020. Lexington, Kentucky: University Press of Kentucky. DOI: https://doi.org/10.2307/j.ctvx0786x.

2. Загорка, О. М., Колесников, В. О., Коваль, В. В., Загорка І. О. До питання застосування розвідувально-ударних і розвідувальновогневих комплексів у мережецентричній війні. Наука і техніка Повітряних Сил Збройних Сил України, 2012, 3(9), С. 8-13.

3. Zahorka, A., Shchypanskyi, P., Pavlikovskyi, A., Koretskyi, A., Bychenkov, V. Devising methodological provisions for the comparative evaluation of variants for an armament sample in terms of militarytechnical level, 2019, 4(3 (100)), pp. 63-72. doi: http://dx.doi.org/ 10.15587/1729-4061.2019.176411.

4. Катулев А.Н., Северцев Н.А. Математические методы в системах поддержки выбора решений: учеб. пособие. Москва. Высшая школа. 2005. $311 \mathrm{c}$.

5. Ларичев О.И., Петровский А.Б. Системы поддержки выбора решений: современное состояние и перспективы развития. Итоги науки и техники. Москва. Высшая школа. т. 21. 1987. 323 с.

6. Ларичев О.И., Мошкевич Е.М. Качественные методы принятия решений. Москва. Наука, 1996. 401с

7. Макаров И.М., Виноградская Т.М., Рубчинский А.А., Соколов В.Б. Теория выбора и принятия решений. Москва. Наука, 1982. 330 с. 